\title{
The meaning of persons in medicine
}

\author{
This article was published in the following Dove Press journal: \\ Journal of Healthcare Leadership \\ I July 2013 \\ Number of times this article has been viewed
}

\section{Peter J Nolan}

Department of Internal Medicine, Toowoomba Hospital, Toowoomba, QLD, Australia; Rural Clinical School, University of Queensland School of

Medicine, Toowoomba, QLD, Australia

\begin{abstract}
Modern health care is at risk of dehumanizing the patient encounter. Pressures of containing costs, maintaining efficiency, and benchmarking with scientific advancements may blur the essential responsibility of medicine: to care for the sick person. Mechanisms common in most health systems have already transformed the sick person from an individual to a numerated entity. Reflecting on three personal vignettes, the subtlety of this trend is highlighted and the challenge to maintain humanness is explored.
\end{abstract}

Keywords: ethics, patient focus, commitment, clinical care, humanness

\section{Introduction}

Working as an intern presents one with a steep learning curve. Upon commencing duties, necessity immediately focuses the mind. Daily challenges motivate a new "hands-on" learning process, and the practical application of knowledge already internalized occurs at breakneck speed. Of enduring impact for me, however, was not the professional development coming from therapeutic or procedural experiences, but rather a profound understanding of the intrinsic needs of persons presenting as patients. The pivotal event for me is as vivid today as when it occurred 30 years ago. It was late on a Saturday night and near the end of a busy 16-hour shift. There had been no meal break, and the line of sick and injured persons seemed endless. As a matter of course, I slipped into a system of mechanical processing, running from one cubicle to the next to hurriedly move the patients through on a diagnostic or management pathway.

\section{Vignettes}

In the next cubicle was a timid young woman who spoke in withdrawn tones. A history about an offensive vaginal bleeding was frustratingly extracted, and I curtly instructed the patient to disrobe and lie under the sheet while I sought a nursing staff member as a chaperone. Rushing then to keep the triage pace moving, I was abruptly stopped in my pressured momentum when the woman suddenly yelled at me, "No, I won't do it!" Stunned by her blatant refusal, I was aware of my own feelings of intense anger until I was unexpectedly calmed by a single moment of gifted grace. I turned to the shaking figure and sat down beside her. Time has absorbed the words I must have spoken, but time has not erased the sound of her sobs of anguish as she told me her intimate story of loss. Only ten days earlier she had attended the same hospital for the delivery of her first child. The labor was long and protracted, and as a result of poor management,
Correspondence: Peter J Nolan

Department of Internal Medicine, Toowoomba Hospital, Pechey Street,

Toowoomba 4350, QLD, Australia

Tel +61746166703

Fax $+6 \mid 746380917$

Email peter.nolan59@me.com 
the child was stillborn. Until that poignant moment, I had managed her as an object, a problem, a disease, a case for processing and analysis!

I recall the sobering words of Thomas Merton, "To consider persons and events and situations only in the light of their effect upon myself is to lie on the doorsteps of hell."'(p24) What does it mean to genuinely value someone - to value a person? It must mean to consider their unique formation, to appreciate their special contribution to collective creation and to genuinely care for their wellbeing and justly defend their cause. "For we must not only seek the truth in those around us, we must find it there. But when we find the truth that shapes our lives we have found more than an idea. We have found a Person." ${ }^{\text {(p9) }}$

More recently, I was offended by a phone call to my office from the hospital's radiology department. The unidentified operator's voice at the other end abruptly inquired, "We have that abdomen you sent down on the table, but we weren't sure what you were specifically looking for." It took me a few moments to realize that the radiographer was talking about Mrs Jones, who had ongoing abdominal pain, and earlier that day we had requested a computed tomography scan of her abdomen. This hardworking, middle-aged farm wife had been transformed in an instant of abstract medical terminology into a mere object undergoing a mechanical process. How readily we slip into jargon that diminishes our relationships with each other, both personal and professional. As human persons, we are surely the most important and unique commodity in this world, and as such, we need to respect our associations and interactions.

Consider the outcome if we allow impersonal systems to remove our fundamental humanness and replace us with record numbers, security codes, passwords, and other inanimate catalogues. Consider what it may be like to be a nonperson. Consider the impact on our society if we forget the meaning of persons.

One of my most empty individual moments occurred when I was pushed to my limits of personal self-esteem and awareness - a time when I felt like a nonentity, a nonperson. I had been on a voluntary aid program overseas in a society under authoritarian rule, and I had been isolated and ostracized by the autocratic organizers in the host country. The regional health "system" officials did not really want any help and had only accepted the offer of professional exchange for politically convenient purposes. So profound was the effect of this depersonalizing loneliness over many weeks that, when I went to withdraw money from an international bank, I could not even remember how to write my own name! I had assumed the status of a nonperson. This covert process of depersonalization was like "Big Brother" of George Orwell's 1984, who erased people by classing them as "unpersons." Their record of existence was conveniently "deleted" from the list of citizens and their whereabouts was no longer of concern. They had been eliminated in fact and in person. Damnatio memoriae.

\section{Reflection}

For the first time in my professional life I realized why I was able to walk past the street beggar, the apoplectic alcoholic in the gutter, or the malodorous homeless person in the waiting room. It was because I subconsciously stratified them as subpersons, and I did not identify with them as part of the breadth of humanity of which I was part. It was a subconscious decision to actually deny my own intrinsic brokenness, to consider myself more deserving than the rest of mankind. As a result, I could ignore them and move on. I could deliver to a select few more "appropriate" and "worthwhile" care. Because of my sociological and economic rationalization, I was potentially denying their essential personhood. In denying their personhood I could be denying them, in practice, proper care. In modern health care, we are being challenged to reconsider the fundamental concept of genuine commitment and involvement in patient care, which Albert Schweitzer describes as a "fellowship of those who bear the mark of pain."2(p17) Our respect for persons deserves a sacred quality. How can we expect the impoverished sick to take better care of themselves with primary and secondary prevention if we don't show them individual respect and attention? True ethical care needs to elevate the actual person with sickness to the pedestal of priority, not the health care system or the disease management process. It is the essence of delivering ethical care. "A man is ethical only when life is holy to him."'2(p87)

\section{Conclusion}

Contemporary health care delivery needs to be person focused, not just in name but in practice. The practice needs to start at the first point of contact with each sick person and followed consistently, like a companion on the journey, until the destination is reached. For many of my patients, the destination is the door to eternity. So be it, my commitment should be nonetheless. What strategies exist to enhance our respect and acknowledgment of each individual's personhood? We could start by identifying them according to their name, not as "that case," "bed four," "cubicle seven," or "record number 123456." We could greet them personably. We could stand 
up and respect them as they enter, like a guest to our own house. We could inquire as to how they really are coping. We could listen for a few moments. We could be gentle. We could touch them.

Our systems need to place the patient first. Administrations should consider placing the patient, not the chief executive officer, at the top of the organizational pyramid structure. Our mission statements and corporate values need to be realigned to the person, not to the "public" or the "consumer" or the "client." Our care of the sick is not a business investment but a service. We need to truly embrace the meaning of persons. Schweitzer went so far as to say that "the future of humanity depends upon each person striving in whatever situation he finds himself, to manifest true humanity to men."2(p54)
Perhaps personhood is the renaissance required in modern health care to balance technological development and its cost-utility. Ultimately, medicine would not exist without persons.

\section{Disclosure}

The author reports no other conflict of interest in this work.

\section{References}

1. Merton T. No Man is an Island. Orlando, FL: Harcourt, Inc; 1955.

2. Schweitzer A. Pilgrimage to Humanity. New York, NY: Philosophical Library; 1961.
Journal of Healthcare Leadership

\section{Publish your work in this journal}

The Journal of Healthcare Leadership is an international, peer-reviewed, open access journal focusing on leadership for the health profession. The journal is committed to the rapid publication of research focusing on but not limited to: Healthcare policy and law; Theoretical and practical aspects healthcare delivery; Interactions between healthcare and society and evidence-based practices;

\section{Dovepress}

Interdisciplinary decision-making; Philosophical and ethical issues; Hazard management; Research and opinion for health leadership; Leadership assessment. The manuscript management system is completely online and includes a very quick and fair peer-review system. Visit http://www.dovepress.com/ testimonials.php to read real quotes from published authors.

Submit your manuscript here: http://www.dovepress.com/journal-of-healthcare-leadership-journal 